Research Journal of Applied Sciences, Engineering and Technology 6(23): 4413-4423, 2013

DOI:10.19026/rjaset.6.3445

ISSN: 2040-7459; e-ISSN: 2040-7467

(C) 2013 Maxwell Scientific Publication Corp.

Submitted: February 12, $2013 \quad$ Accepted: March 03, $2013 \quad$ Published: December 15, 2013

\title{
Research Article Designing a Model for Dynamic Capabilities Evaluation in Equipment Manufacturing Enterprises of Iran Power Industry
}

\author{
${ }^{1}$ Ashraf Sadat Pasandideh, ${ }^{2}$ Reza Salami, ${ }^{2}$ Jahanyar Bamdad Soofi and ${ }^{2}$ Maghsud Amiri \\ ${ }^{1}$ Department of Technology Policy-Making, \\ ${ }^{2}$ School of Management and Accounting, Allameh Tabatabaei University, Tehran, Iran
}

\begin{abstract}
This study aims at designing a model for dynamic capabilities evaluation in equipment manufacturing enterprises of Iran power industry. In so doing, enablers and indices of dynamic capabilities four elements (i.e., seizing opportunities, sensing opportunities, innovation implementation and reconfiguration) are identified. Since dynamic capabilities literature is rooted in developed countries, localization of dynamic capability concepts in Iran as a developing country and in the power industry as a main infrastructure of development is a matter of great magnitude. Considering data gathered from more than 100 power industry equipment manufacturers in Iran and gaining the opinions of experts in such fields as innovation management and technology development, the model has been designed and its accuracy will be assessed in the present study.
\end{abstract}

Keywords: Dynamic capabilities, equipment manufacturing enterprises, power industry

\section{INTRODUCTION}

As of publication of Teece primary work in 1997 regarding dynamic capabilities, this issue has been converted into one of the most important research fields in strategic management. From 2006 by present, over 100 papers regarding dynamic capabilities have been published annually in management and business journals. With respect to the growth of research on dynamic capabilities, it may be assumed that there is a common perception regarding these capabilities at the present juncture. It must be noted that this assumption is not right and the structure of dynamic capabilities issue, even as regards fundamental aspects of this concept (dynamic capabilities definition) is completely open. In general, one can state that dynamic capabilities is an issue that branches into different and distinct aspects and different researchers have developed different aspects; so the lines of their thoughts become further distinct (Di Stefano, 2010). With respect to the novelty of dynamic capabilities issue, the focus of interest is different among different scholars. Such issues as effective conditions, the effect of these capabilities on the enterprise performance and the nature of these dynamic capabilities have each drawn attention of some scholars (Prieto, 2009).

Recently, researchers have become interested in sensing dynamic capabilities in product development. Product development is inherently an activity based on knowledge that underscores learning and knowledge process for development, production and distribution of new products (Danneels, 2002). Product development process allows organizations to reconfigure their vital tasks to integrate sporadic knowledge that are distinct in terms of nature in an innovation path so as to create new effective knowledge. Thus several studies have considered product development in the form of an ideal framework in which dynamic capabilities can be assessed (Prieto, 2009).

Another point that may be referred is that dynamic capabilities literature is rooted in developed countries; hence the nature of dynamic capabilities is not such known in developing countries.

Given the above mentioned points, this study has taken into account the issue of dynamic capabilities in line with technological products development in enterprises of such developing countries as Iran and in an infrastructural industry, i.e., power industry. As is evident, one of the important elements in the power industry is manufacturer who products the required equipments of this industry in different areas of the power grid (production, transmission and distribution of electrical energy). Applying proper and efficient technological products in the power grid plays a valuable rule in providing appropriate services in this industry.

Surveys reveal that Iranian manufacturers of the power grid equipments are often engaged in routine operational processes, so their activities in technology development and innovation are restricted. Such an approach towards technology development has faded

Corresponding Author: Ashraf Sadat Pasandideh, Department of Technology Policy-Making, School of Management and Accounting, Allameh Tabatabaei University, Tehran, Iran

This work is licensed under a Creative Commons Attribution 4.0 International License (URL: http://creativecommons.org/licenses/by/4.0/). 
the name of some traditionally famous enterprises or has harmed the fame of some enterprises.

The present study first explains briefly dynamic capabilities. Then focusing on Iranian equipments manufacturers in power industry, it refers to the design stages of the model of dynamic capabilities evaluation in the country power industry enterprises. It must be noted that since in the present study a model for evaluating the status of dynamic capabilities in the equipments manufacturers of the power industry is introduced, it is an applied research. Besides, since the concept of dynamic capabilities in manufacturers of technological products in a developing country like Iran is a new issue, it plays a role in developing theoretical foundations of dynamic capabilities.

\section{LITERATURE REVIEW}

"Dynamic capability is the enterprise ability to integrate, build and reconfigure internal and external qualifications in response to the rapidly changing environment" (Teece et al., 1997).

Given the definitions of dynamic capabilities, different experts agree on below items in this regard:

- Dynamic capabilities are organizational processes/routine tasks that are rooted in knowledge (Ambrosini and Bowman, 2009).

- The outputs of dynamic capabilities are new forms of operational routine tasks and resources (Cepeda, 2007).

- Dynamic capabilities must be built and they cannot be purchased from market.

- Dynamic capabilities are path dependent.

- Dynamic capabilities are embodied in the enterprise (Ambrosini and Bowman, 2009).

- Learning process is the main element in building and updating dynamic capabilities (Prieto, 2009).

Another salient point is that there is distinction between operational capabilities and dynamic capabilities. Operational/technical capabilities are identified in such items as inputs order, purchase, financial control, inventory control, financial reports, marketing and sale, etc., the management of these tasks is regarded as operational management (Teece, 2009). On the contrary, dynamic capabilities are considered as the organization high level capabilities that provide the stage of learning new areas, creating new combinations of inventories and new capabilities in order to be adapted with market needs. Dynamic capabilities comprise the processes required for sensing new commercial opportunities and coordinating the resources portfolio with considering changing conditions (Ellonen, 2009).

Nowadays, enormous efforts are undertaken by researchers in this regard from different aspects. Some have taken into account the nature of these capabilities and have presented different classifications of dynamic capabilities examples. Some have considered the effective conditions on these capabilities and some have focused on the effect of dynamic capabilities on the enterprise performance (Prieto, 2009).

\section{DESIGN STAGES OF THE DYNAMIC CAPABILITIES EVALUATION MODEL IN EQUIPMENT MANUFACTURERS OF IRAN POWER INDUSTRY}

To design a model for dynamic capabilities evaluation in equipments manufacturers of power industry, different steps have been taken that are presented in the following.

Selecting elements, aspects and indices of dynamic capabilities: Reviewing dynamic capabilities literature reveal that different classifications have been offered by different scholars regarding these capabilities (Verona and Ravasi, 2003; Helfat, 1997; Teece, 2007; Bowman and Ambrosini, 2003; Danneels, 2002; Zahra and George, 2002). The present study has adopted the classification offered by Teece and Danneels, as both have considered these capabilities with an approach towards innovation development in the enterprise. Due to the fact that technology development and innovation have been disregarded in Iranian equipments manufacturing enterprises of power industry, dynamic capabilities elements that are effective on this process are introduced in the study primary model as per below:

- Capability of sensing opportunities: The enterprise ability in detecting operational environment changes and sensing new opportunities.

- Capability of seizing opportunities: The enterprise ability in creating and providing structures that improve creativity and innovation in the enterprise.

- Capability of implementing innovation: The enterprise ability in managing innovation projects implementation

- Capability of reconfiguration: The enterprise ability in readjusting the available resources.

Each of the above capabilities has stemmed from enablers that have been considered by different researchers in innovation and dynamic capabilities literature. To study enablers, indices are required. These indices are selected by studying the related literature, taking into account the properties of the country power industry and the activity type of equipments manufacturers in the area of electrical energy transmission and distribution; and then a primary model is drawn with 4 dynamic capabilities, 19 enablers and 84 indices. Comments of experts in innovation and technology management and some managers in Iran 
Power Industry who have had experiences in technology management in this industry have been applied to assess this model. Having gathered the opinions and analyzed them, among 19 enablers, 17 elements were approved and among 84 indices, 28 indices were not approved. Also 9 indices were added to the set of indices as per experts' opinions. So the primary model was modified and the Fig. 1 was attained.
Research tools design: In this study in which a survey research method has been applied, the most important tool is questionnaire. In the questionnaire, two questions have been designed for the Fig. 1 indices. Respondents were asked to state the importance of each index by considering 5-point Likert scale and then indicate the attention level that is paid to the indices in their respective enterprises.

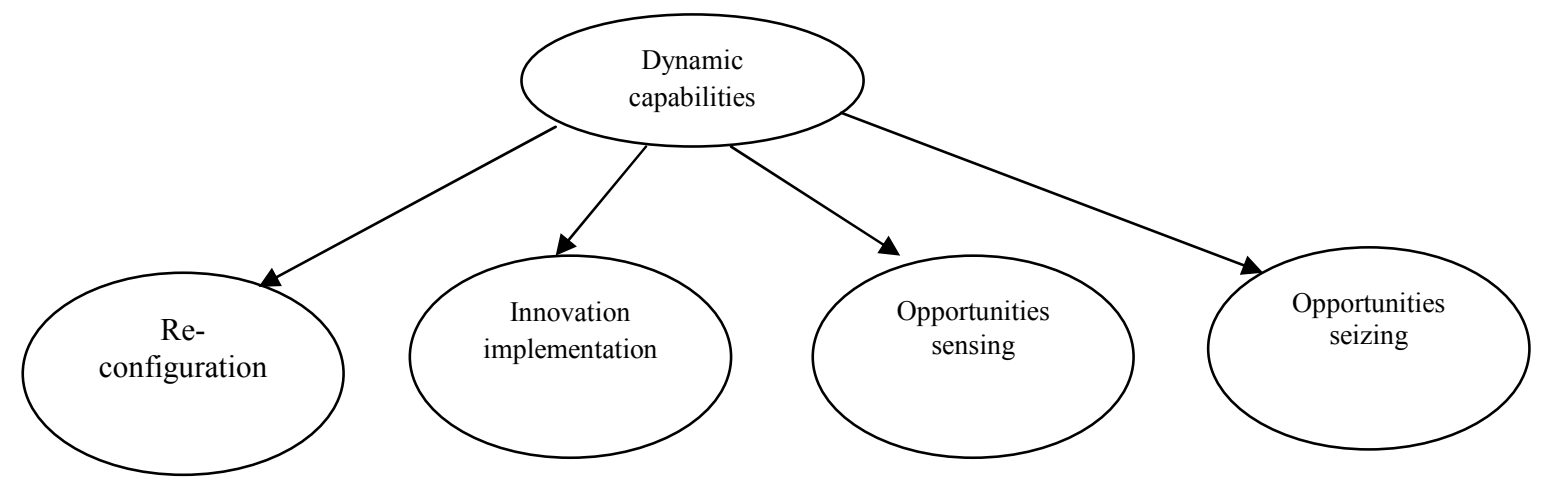

Fig. 1: (a) Dynamic capabilities elements

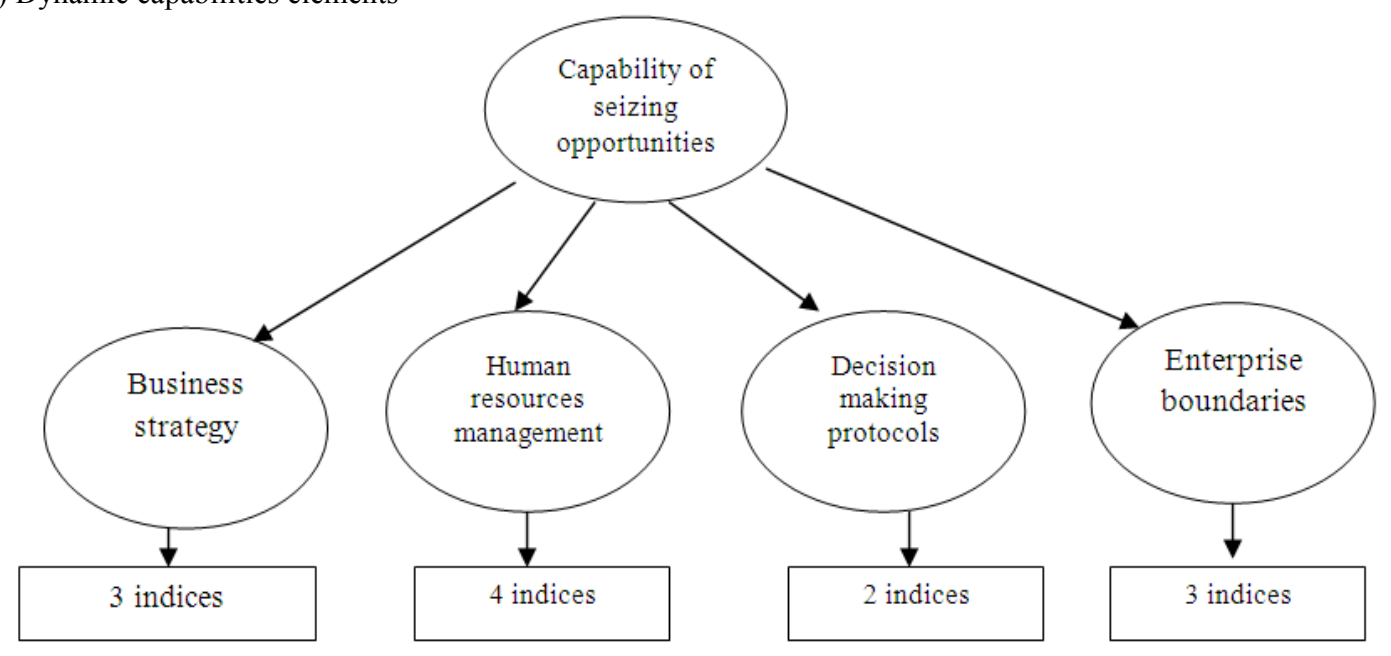

Fig. 1: (b) Enablers and indices of capability of seizing opportunities

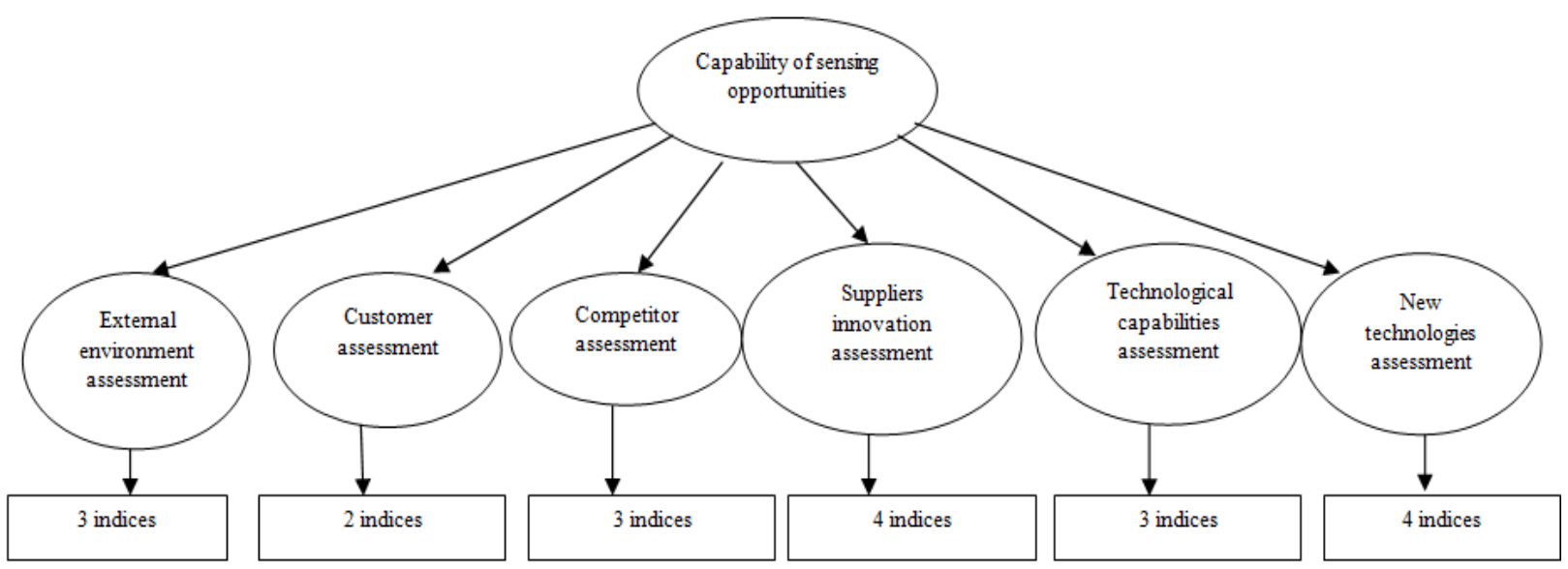

Fig. 1: (c) Enablers and indices of capability of sensing opportunities 


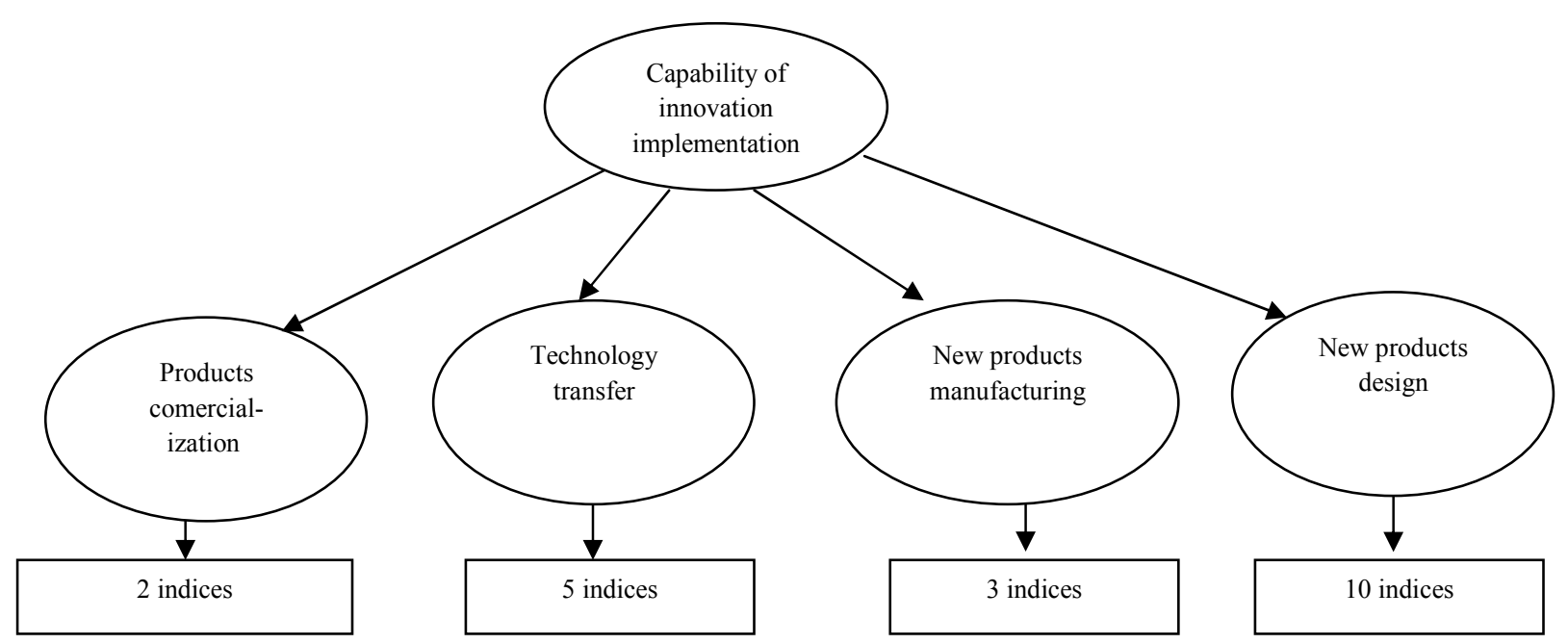

Fig. 1: (d) Enablers and indices of capability of implementing innovations

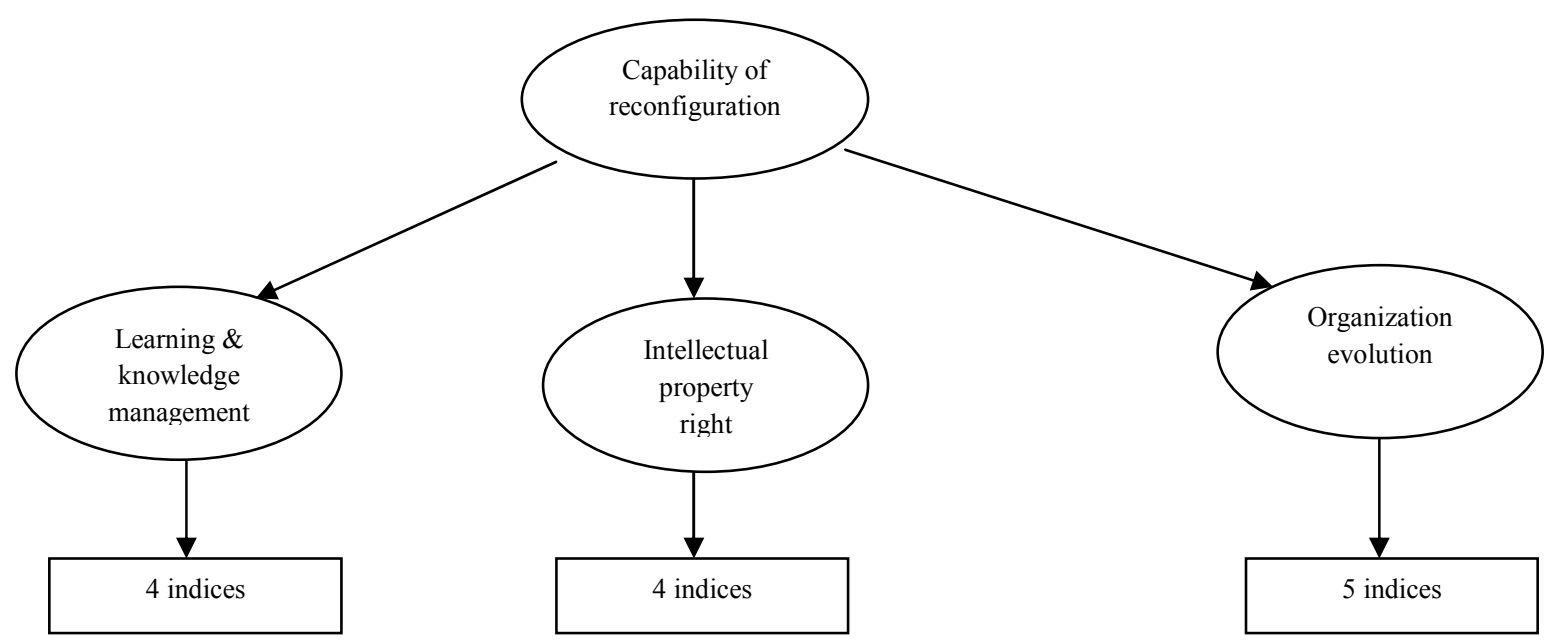

Fig. 1: (e) Enablers and indices of capability of reconfiguration

Statistical population: Statistical population of this study is comprised of equipments manufacturing enterprises in power industry which have been members of Iran Power Industry Syndicate committees in different areas of electrical energy production, transmission and distribution and they have been active in the field of manufacturing plant equipments, capacitor, rig, energy transmission lines, rod and cutout fuse, electrical panels, relay and laboratory equipments, transformer, electrical switches in various voltages, energy transmission equipments, wire and cable, insulator and accessories of electrical systems. Total number of statistical population is 280 companies active in the above mentioned three areas. 30 companies are active in electrical energy production, 70 companies in electrical energy transmission, 145 companies in electrical energy distribution and 35 companies in more than one area. With regard to the statistical population volume, Cochran formula has been adopted to determine sample volume as equaling
102. Through using stratified sampling method, 52, 26, 11 and 13 companies will be respectively active in distribution sector, transmission sector, production sector and common areas. 250 questionnaires were sent to all related companies. With numerous follow-ups in a three- month period, 108 acceptable questionnaires were ultimately gathered.

Confirming model validity through confirmatory factor analysis: With respect to the collected data, confirmatory factor analysis along with LISREL software has been adopted to confirm the model validity in each sector. Confirmatory factor analysis is in fact a theory model test in which the researcher commences its analysis with a pre-assumption. The model, being based on strong empirical and theoretical foundations, specifies that which variable must be associated with each factor. It also provides the researcher with a reliable method to evaluate the construct reliability so as to test clearly the hypotheses 
regarding data factor structure caused by a predetermined model with specified number and combination of factors (Human, 2008). In the following, results of confirmatory factor analysis for each dynamic capability element have been presented (Fig. 2 to 5 ).

\section{RESULTS INTERPRETATION}

Figure 2 to 5 depict second-order factor analysis models for dynamic capabilities elements namely seizing opportunities, sensing opportunities, innovation implementation and reconfiguration, in estimating
Goodness of fit Statistics:

Chi-Square $=84.72, \quad d f=50,\left(X^{2} / d f=1.694\right), \quad$ RMSEA $=0.081$

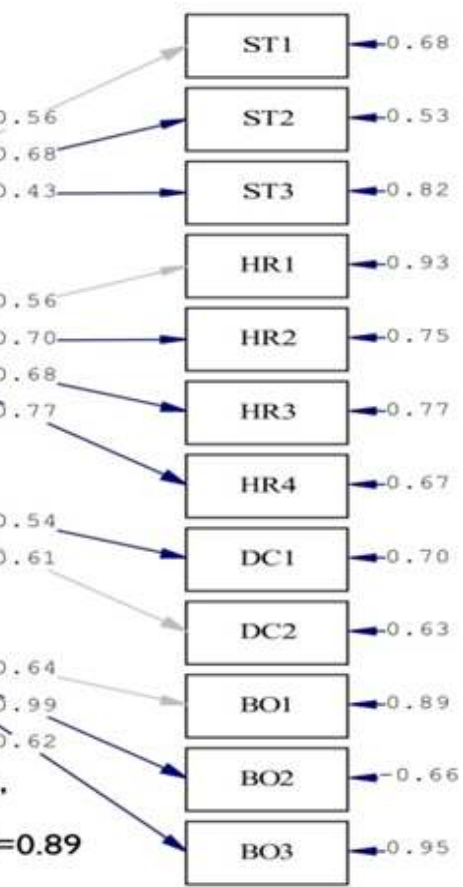

Fig. 2: Second-order confirmatory factor analysis of seizing opportunities after modifications in estimating standard coefficients

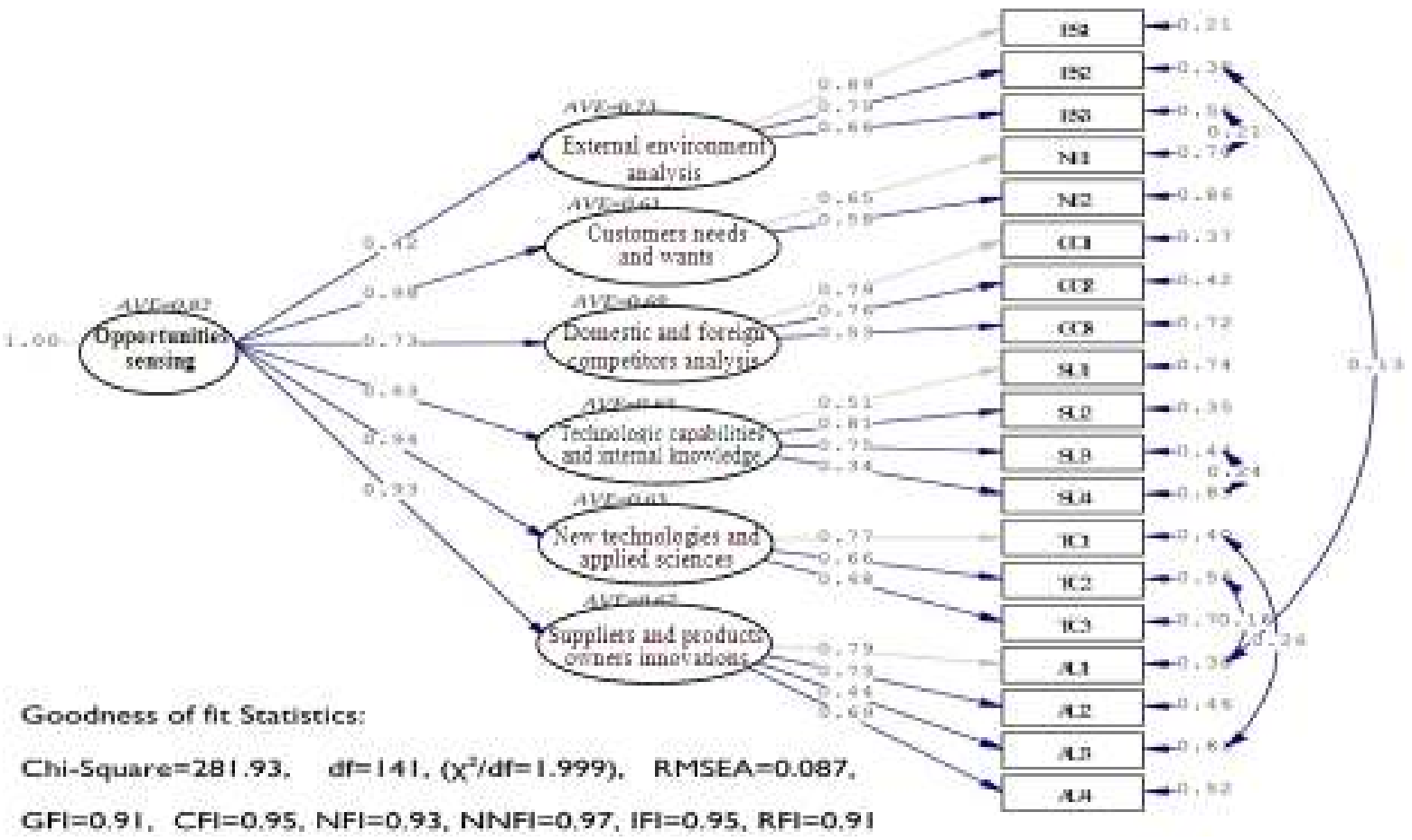

Fig. 3: Second-order confirmatory factor analysis of sensing opportunities after modifications in estimating standard coefficients 
standard coefficients. All the research variables are divided into two groups of manifest and latent variables. Manifest (rectangular) or observed variables are the questionnaire indices whose importance have been specified by the respondents via Likert scale; so they have been measured directly. Whereas latent (oval) or non-observed variables are dynamic capabilities and enablers that are not measured directly, but rather based on the relations or correlations among measured variables.

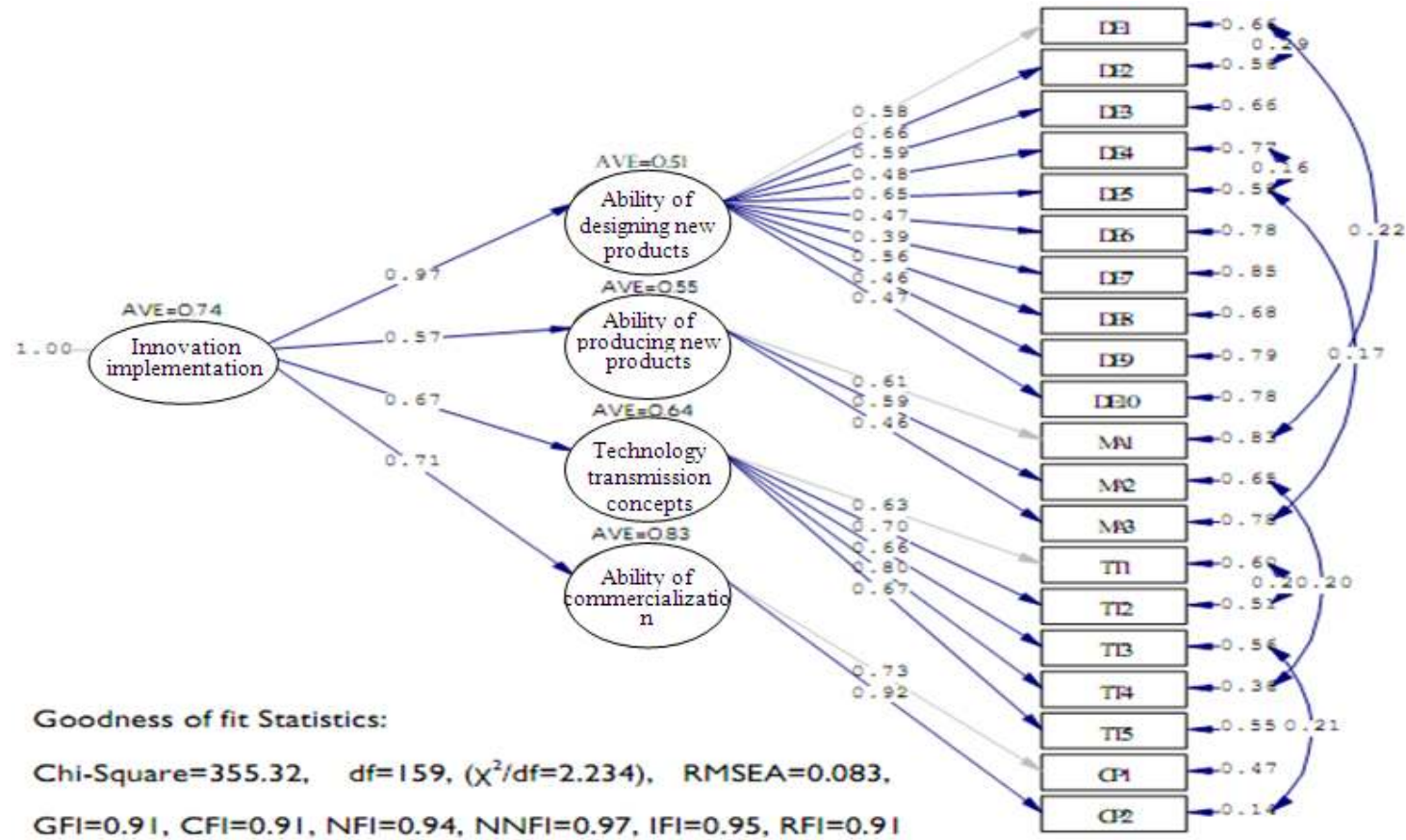

Fig. 4: Second-order confirmatory factor analysis of implementing innovation after modifications in estimating standard coefficients

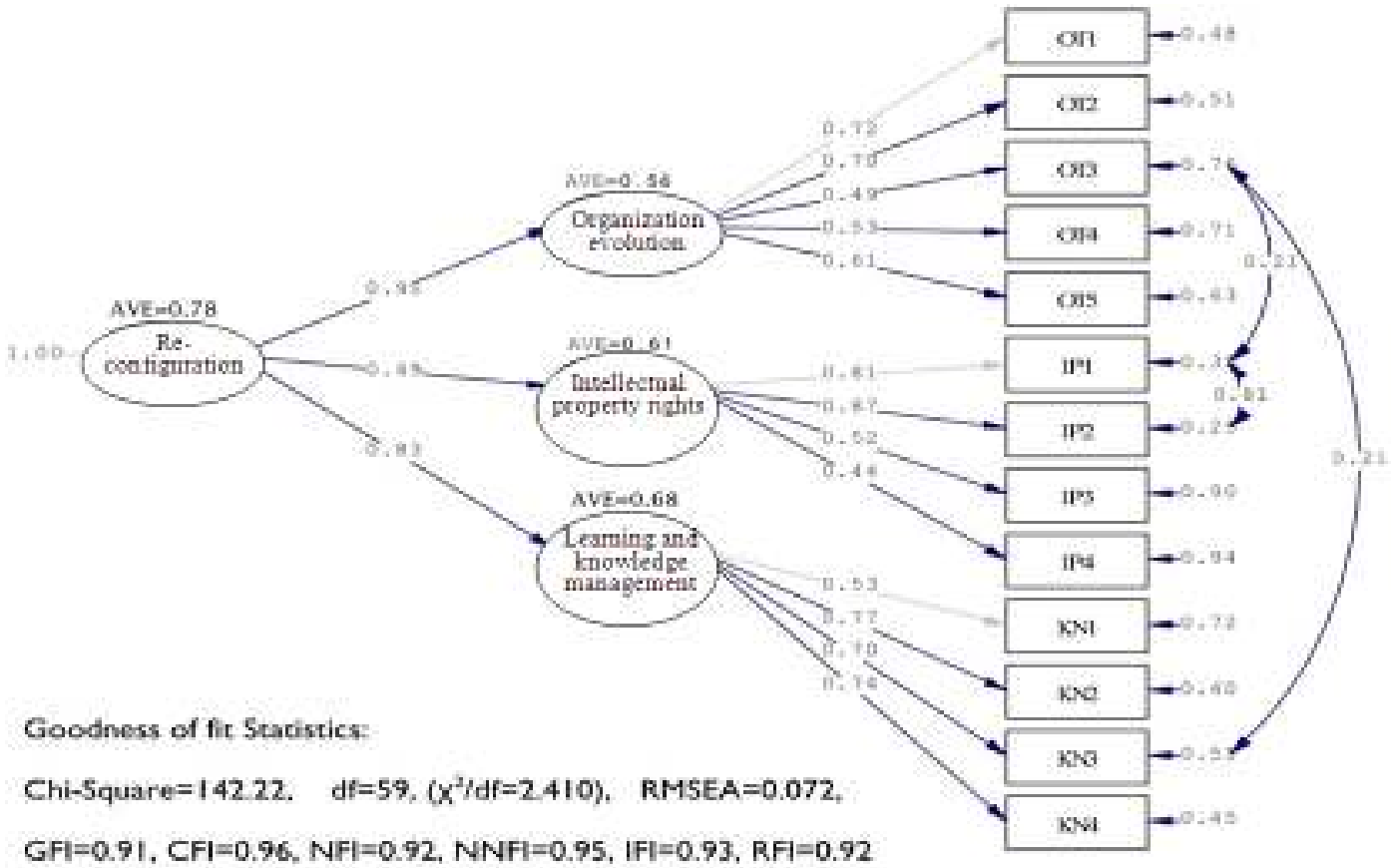

Fig. 5: Second-order confirmatory factor analysis of reconfiguration in estimating standard coefficients 
In the above figures, numbers and coefficients are divided into two groups. First group is comprised of first- order equations that measure the relation between latent variables namely enablers and manifest variables i.e., indices and constitute first-order confirmatory factor analysis. These equations are called first- order loading factor. Second group is second-order equations that measure the relation between latent variables (the relation between enablers and dynamic capabilities) and these coefficients are known as second-order confirmatory factor analysis. Since the coefficients are standard, they can be compared with each other. As per standard loading factors, the index that has the highest loading factor contributes more to the related variable measurement.

Significance of measurement coefficients To assess coefficients significance of Fig. 2 to 5, second-order factor analysis model has been adopted in the state of coefficients significance (t-value). This model tests all first-and second-orders equations (loading factor) by using $t$ statistic. As per this model, loading factor is

Table 1: The results of first-and second-order confirmatory factor analysis for opportunities seizing model

\begin{tabular}{|c|c|c|c|c|c|}
\hline Latent variables & Observed variables & $\begin{array}{l}\text { Loading } \\
\text { factor }\end{array}$ & t statistic & sig. & Result \\
\hline \multirow[t]{3}{*}{$\begin{array}{l}\text { Business strategy } \\
\text { (business model) }\end{array}$} & $\begin{array}{l}\text { Determining the enterprise investment priorities in } \\
\text { power industry }\end{array}$ & 0.56 & Constant & $<0.01$ & Significant \\
\hline & Determining the enterprise target market segments & 0.68 & 4.82 & $<0.01$ & Significant \\
\hline & $\begin{array}{l}\text { Determining the enterprise income structure and } \\
\text { business cost }\end{array}$ & 0.43 & 3.50 & $<0.01$ & Significant \\
\hline \multirow{2}{*}{$\begin{array}{l}\text { Effective human } \\
\text { resources }\end{array}$} & System of receiving staff suggestions & 0.56 & Constant & $<0.01$ & Significant \\
\hline & Training multi functional staff & 0.70 & 2.21 & $<0.05$ & Significant \\
\hline management & System of staff experiences management & 0.68 & 2.19 & $<0.05$ & Significant \\
\hline \multirow{3}{*}{$\begin{array}{l}\text { innovation process } \\
\text { Enterprise decision } \\
\text { making protocols }\end{array}$} & System of group performance management & 0.77 & 2.27 & $<0.05$ & Significant \\
\hline & $\begin{array}{l}\text { Lack of effective methods and routines formed during } \\
\text { past years (dependency upon the path) on the enterprise } \\
\text { decision making }\end{array}$ & 0.54 & Constant & $<0.0 .1$ & Significant \\
\hline & $\begin{array}{l}\text { Lack of enterprise tendency towards decisions with } \\
\text { determined and low- risk outputs (the effect of } \\
\text { confidence) }\end{array}$ & 0.61 & 4.59 & $<0.01$ & Significant \\
\hline \multirow{3}{*}{$\begin{array}{l}\text { Enterprise } \\
\text { boundaries } \\
\text { determination }\end{array}$} & $\begin{array}{l}\text { Outsourcing construction of some sub- systems of final } \\
\text { products }\end{array}$ & 0.64 & Constant & $<0.01$ & Significant \\
\hline & Alliance with other enterprises & 0.99 & 2.55 & $<0.05$ & Significant \\
\hline & $\begin{array}{l}\text { Purchasing other enterprises (in order to achieve their } \\
\text { special resources and equipments in the new products } \\
\text { development process) }\end{array}$ & 0.62 & 2.63 & $<0.01$ & Significant \\
\hline \multirow{4}{*}{$\begin{array}{l}\text { Seizing } \\
\text { opportunities }\end{array}$} & Business strategy formulation & 0.98 & 5.37 & $<0.01$ & Significant \\
\hline & $\begin{array}{l}\text { Effective human resources management in the } \\
\text { innovation process }\end{array}$ & 0.98 & 5.38 & $<0.01$ & Significant \\
\hline & Enterprise decision making protocols & 0.99 & 6.40 & $<0.01$ & Significant \\
\hline & Enterprise boundaries determination & 0.33 & 3.36 & $<0.01$ & Significant \\
\hline
\end{tabular}

Table 2: The results of second-order confirmatory factor analysis for opportunities sensing model

\begin{tabular}{|c|c|c|c|c|c|}
\hline Latent variables & Observed variables & $\begin{array}{l}\text { Loading } \\
\text { factor }\end{array}$ & t-statistic & Sig. & Result \\
\hline \multirow[t]{3}{*}{$\begin{array}{l}\text { External } \\
\text { environment analysis }\end{array}$} & $\begin{array}{l}\text { Scenario analyses regarding the future of Iran power } \\
\text { industry and market }\end{array}$ & 0.89 & Constant & $<0.01$ & Significant \\
\hline & $\begin{array}{l}\text { Trend analyses regarding such issues as power } \\
\text { consumption increase, increase in demand of } \\
\text { enterprise produced equipments in power industry, } \\
\text { load intensity, etc. }\end{array}$ & 0.79 & 8.07 & $<0.01$ & Significant \\
\hline & $\begin{array}{l}\text { Analysis of policies, plans,... of domestic and } \\
\text { international firms in energy particularly electrical } \\
\text { energy field }\end{array}$ & 0.66 & 7.08 & $<0.01$ & Significant \\
\hline \multirow[t]{2}{*}{$\begin{array}{l}\text { Enterprise customers } \\
\text { needs and wants } \\
\text { assessment }\end{array}$} & $\begin{array}{l}\text { Quantitative and qualitative evaluations regarding } \\
\text { manifest and latent needs of enterprise customers in } \\
\text { power industry }\end{array}$ & 0.65 & Constant & $<0.01$ & Significant \\
\hline & $\begin{array}{l}\text { Applying "internet communication" mechanisms for } \\
\text { receiving customers needs and wants }\end{array}$ & 0.58 & 3.20 & $<0.01$ & Significant \\
\hline $\begin{array}{l}\text { Analysis of } \\
\text { enterprise domestic }\end{array}$ & $\begin{array}{l}\text { Competitors benchmark analyses (domestic and } \\
\text { foreign competitors) }\end{array}$ & 0.79 & Constant & $<0.01$ & Significant \\
\hline and foreign & Analysis of alternative and competitors products & 0.76 & 6.66 & $<0.01$ & Significant \\
\hline competitors & Assessing patents registered by competitors & 0.53 & 4.94 & $<0.01$ & Significant \\
\hline
\end{tabular}


Res. J. Appl. Sci. Eng. Technol., 6(23): 4413-4423, 2013

Table 3: The results of second-order confirmatory factor analysis for innovation implementation model

\begin{tabular}{|c|c|c|c|c|c|}
\hline$\underline{\text { Latent variables }}$ & Observed variables & $\begin{array}{l}\text { Loading } \\
\text { factor }\end{array}$ & t statistic & Sig. & Result \\
\hline \multirow{10}{*}{$\begin{array}{l}\text { Products design } \\
\text { capability }\end{array}$} & Layout design of new products in the enterprise & 0.58 & Constant & $<0.01$ & Significant \\
\hline & $\begin{array}{l}\text { Design of new products components in the enterprise } \\
\text { (basic and detailed design) }\end{array}$ & 0.66 & 7.25 & $<0.01$ & Significant \\
\hline & $\begin{array}{l}\text { Simplicity considerations (considering less active } \\
\text { parts in designing new products) }\end{array}$ & 0.59 & 4.77 & $<0.01$ & Significant \\
\hline & $\begin{array}{l}\text { "concurrent engineering" in new products } \\
\text { development process }\end{array}$ & 0.48 & 4.05 & $<0.01$ & Significant \\
\hline & $\begin{array}{l}\text { Formation of cross functional cooperation for design } \\
\text { and development of new products in the enterprise }\end{array}$ & 0.65 & 5.16 & $<0.01$ & Significant \\
\hline & $\begin{array}{l}\text { Applying information systems (CAD, CAE, CAPP) } \\
\text { in design- engineering department }\end{array}$ & 0.47 & 4.04 & $<0.01$ & Significant \\
\hline & $\begin{array}{l}\text { Applying LANs in design department to } \\
\text { communicate with internal departments and } \\
\text { exchange with customers and suppliers }\end{array}$ & 0.39 & 3.44 & 0.01 & Significant \\
\hline & $\begin{array}{l}\text { Enterprise relationship with customers during new } \\
\text { product development process }\end{array}$ & 0.56 & 4.63 & $<0.01$ & Significant \\
\hline & $\begin{array}{l}\text { Cooperation with designer companies and or } \\
\text { research companies in power industry regarding new } \\
\text { products design }\end{array}$ & 0.46 & 3.93 & $<0.01$ & Significant \\
\hline & Proto typing the related products by enterprise & 0.47 & 4.03 & $<0.01$ & Significant \\
\hline \multirow[t]{3}{*}{$\begin{array}{l}\text { Ability of building } \\
\text { and producing new } \\
\text { products }\end{array}$} & $\begin{array}{l}\text { Applying advanced production technologies } \\
\text { including CNC, DNC, robotics, AGV in new product } \\
\text { manufacturing process }\end{array}$ & 0.61 & Constant & $<0.01$ & Significant \\
\hline & $\begin{array}{l}\text { Applying integrated information systems including } \\
\text { MRP, MRPII }\end{array}$ & 0.59 & 2.62 & $<0.01$ & Significant \\
\hline & $\begin{array}{l}\text { Possessing "exclusive equipments" for } \\
\text { manufacturing new products }\end{array}$ & 0.46 & 2.54 & $<0.05$ & Significant \\
\hline \multirow{5}{*}{$\begin{array}{l}\text { Familiarity with } \\
\text { technology } \\
\text { transmission } \\
\text { concepts }\end{array}$} & $\begin{array}{l}\text { Analyses related to sensing and evaluating technical } \\
\text { knowledge/ technologies required by the enterprise } \\
\text { from external resources }\end{array}$ & 0.63 & Constant & $<0.01$ & Significant \\
\hline & $\begin{array}{l}\text { Analyses related to sensing and evaluating suppliers } \\
\text { of technical knowledge/ technologies required by } \\
\text { enterprise }\end{array}$ & 0.70 & 7.60 & $<0.01$ & Significant \\
\hline & $\begin{array}{l}\text { Familiarity of the enterprise with negotiation } \\
\text { techniques with owners of technical knowledge/ } \\
\text { technology }\end{array}$ & 0.66 & 5.57 & $<0.01$ & Significant \\
\hline & $\begin{array}{l}\text { Familiarity of the enterprise with different } \\
\text { technology transmission contracts and related legal } \\
\text { rules and principles }\end{array}$ & 0.80 & 6.20 & $<0.01$ & Significant \\
\hline & $\begin{array}{l}\text { Using technology transmission methods in line with } \\
\text { new products development }\end{array}$ & 0.67 & 5.54 & $<0.01$ & Significant \\
\hline \multirow[t]{2}{*}{$\begin{array}{l}\text { Commercialization } \\
\text { capability }\end{array}$} & $\begin{array}{l}\text { Market test by enterprise in line with new product } \\
\text { commercialization }\end{array}$ & 0.73 & Constant & $<0.01$ & Significant \\
\hline & $\begin{array}{l}\text { Doing activities such as publishing brochures, } \\
\text { holding conference and workshop, etc., to introduce } \\
\text { new products }\end{array}$ & 0.92 & 6.67 & $<0.01$ & Significant \\
\hline \multirow{4}{*}{$\begin{array}{l}\text { Innovation } \\
\text { implementation }\end{array}$} & Capability of designing new products & 0.97 & 5.77 & $<0.01$ & Significant \\
\hline & Capability of producing new products & 0.57 & 2.68 & $<0.01$ & Significant \\
\hline & Familiarity with technology transmission concepts & 0.67 & 4.94 & $<0.01$ & Significant \\
\hline & Capability of commercialization & 0.71 & 5.14 & $<0.01$ & Significant \\
\hline
\end{tabular}

significant at $95 \%$ confidence level. If $t$-value is outside the range between -1.96 and +1.96 and if t-value is within this range, then loading factor or path coefficient is not significant. Also path coefficient or loading factor is significant at $99 \%$ confidence level if $\mathrm{t}-$ value is outside the range between -2.58 and +2.58 . Table 1 to 4 present the results of assessing measurement coefficients significance of Fig. 2 to 5 . As it is seen, loading factors related to the research constructs have been tested at two $5 \%$ and $1 \%$ error levels. The results indicated that all first- and second- orders loading factors are at confidence levels of $99 \%$ ( $\mathrm{t}$ statistic is outside the range between -2.58 and +2.58$)$ or $95 \%(\mathrm{t}$ statistic is outside the range between -1.98 and +1.98 ) and have succeeded to play a significant role in measuring the related construct.

Goodness of fit assessment: The other point that must be assessed in confirming the model is goodness of fit. In so doing, fit indices such as chi-squared goodness of fit test and secondary indices including Goodness of Fit Index (GFI), Normed Fit Index (NFI) and Adjusted Goodness of Fit Index (AGFI) have been applied. It must be noted that in LISREL software, each index is not by itself the cause of goodness of fit or lack of goodness of fit, but rather they must be interpreted along with each other. Table 5 depicts that the model in 
Res. J. Appl. Sci. Eng. Technol., 6(23): 4413-4423, 2013

Table 4: The results of second-order confirmatory factor analysis for reconfiguration model

\begin{tabular}{|c|c|c|c|c|c|}
\hline Latent variables & Observed variables & $\begin{array}{l}\text { Loading } \\
\text { factor }\end{array}$ & t statistic & Sig. & Result \\
\hline \multirow[t]{5}{*}{$\begin{array}{l}\text { Organization } \\
\text { evolution }\end{array}$} & $\begin{array}{l}\text { Decentralization of enterprise decision making (getting away from } \\
\text { hierarchy structures) }\end{array}$ & 0.72 & Constant & $<0.01$ & Significant \\
\hline & Formation of "enterprise governance" proper system & 0.70 & 6.29 & $<0.01$ & Significant \\
\hline & Separation of ownership from enterprise control & 0.49 & 4.50 & $<0.01$ & Significant \\
\hline & $\begin{array}{l}\text { Applying such techniques as re- engineering and business process } \\
\text { redesign (BPR) }\end{array}$ & 0.53 & 4.93 & $<0.01$ & Significant \\
\hline & $\begin{array}{l}\text { Applying new accounting systems including "activity- based } \\
\text { costing" }\end{array}$ & 0.61 & 5.56 & $<0.01$ & Significant \\
\hline \multirow[t]{4}{*}{$\begin{array}{l}\text { Intellectual } \\
\text { property rights }\end{array}$} & $\begin{array}{l}\text { The amount of patent registration from enterprise specific } \\
\text { knowledge }\end{array}$ & 0.81 & Constant & $<0.01$ & Significant \\
\hline & The amount of "design rights" registration by the enterprise & 0.87 & 5.04 & $<0.01$ & Significant \\
\hline & Enterprise efforts for branding and brand management & 0.52 & 3.06 & $<0.01$ & Significant \\
\hline & Licensing intellectual property rights of other companies & 0.44 & 2.29 & $<0.01$ & Significant \\
\hline \multirow{4}{*}{$\begin{array}{l}\text { Learning and } \\
\text { knowledge } \\
\text { management }\end{array}$} & $\begin{array}{l}\text { Receiving feedbacks from customers regarding developed } \\
\text { products }\end{array}$ & 0.53 & Constant & $<0.01$ & Significant \\
\hline & Documentation of developed projects knowledge & 0.77 & 5.09 & $<0.01$ & Significant \\
\hline & $\begin{array}{l}\text { Designing processes for attaining, sharing, and using developed } \\
\text { knowledge }\end{array}$ & 0.70 & 4.86 & $<0.01$ & Significant \\
\hline & $\begin{array}{l}\text { Applying IT systems for saving, sharing and reusing developed } \\
\text { knowledge }\end{array}$ & 0.74 & 5.00 & $<0.01$ & Significant \\
\hline \multirow[t]{3}{*}{ Reconfiguration } & Organization evolution & 0.82 & 4.51 & $<0.01$ & Significant \\
\hline & Intellectual property rights & 0.75 & 2.36 & $<0.01$ & Significant \\
\hline & Learning and knowledge management & 0.63 & 3.68 & $<0.01$ & Significant \\
\hline
\end{tabular}

Table 5: Goodness of fit indices

\begin{tabular}{|c|c|c|c|c|c|}
\hline Index & Seizing opportunities & $\begin{array}{l}\text { Implementing } \\
\text { innovation }\end{array}$ & $\begin{array}{l}\text { Sensing } \\
\text { opportunities }\end{array}$ & Re-configuration & Limit \\
\hline $\begin{array}{l}\text { The ratio of Chi- squared to freedom } \\
\text { degree }\end{array}$ & 1.694 & 2.234 & 1.999 & 2.410 & Less than 3 \\
\hline GFI (Goodness of Fit Index) & 0.92 & 0.91 & 0.91 & 0.91 & More than 0.9 \\
\hline $\begin{array}{l}\text { RMSEA (Root Mean Square Error of } \\
\text { Approximation) }\end{array}$ & 0.081 & 0.083 & 0.087 & 0.072 & Less than 0.09 \\
\hline CFI (Comparative Fit Index) & 0.95 & 0.91 & 0.95 & 0.96 & More than 0.9 \\
\hline NFI (Normed Fit Index) & 0.92 & 0.94 & 0.93 & 0.92 & More than 0.9 \\
\hline NNFI (Non Normed Fit Index & 0.94 & 0.97 & 0.97 & 0.95 & More than 0.9 \\
\hline
\end{tabular}

dynamic capabilities enjoys a proper status in terms of goodness of fit and all of these indices indicate the model fits the observations; because the ratio of Chisquared to freedom degree is less than 3, RMSEA index is less than 0.09 and the rest indices are acceptable. In other words, the general model is significant and acceptable.

Important indices in measuring dynamic capabilities constructs: As mentioned earlier, in confirmatory factor analysis, the index that has higher loading factor plays a greater role in measuring the related construct. With regard to Table 1 to 4 , following results can be presented briefly.

Construct of seizing opportunities: The results suggest that in business strategy enabler, determining segments of the enterprise target market and then determining the enterprise investment priorities in power industry have been more important. As regards effective human resources management enabler in innovation process, group performance management system and then multi skills staff training and staff experiences management system have been the most important ones. As regards enterprise decision making protocols enabler, both indices of enterprise tendency towards risky decisions and enterprise flexibility towards previously created methods and routines have had an identical role in measuring this enabler. Given enterprise boundaries determination enabler, establishing alliances with other enterprises has been more important. Furthermore, the above mentioned enablers have relatively equally contributed to measuring dynamic capabilities namely seizing opportunities, business strategy formulation, effective human resources management in innovation process and enterprise decision making protocols.

Construct of sensing opportunities: It must be noted that as regards external environment analysis enabler, scenario analyses regarding the future of Iran power industry and power market in different economic, political and social arenas have played greater roles. Concerning customers needs and wants assessment enabler, quantitative and qualitative evaluations of customers needs have been more important. In competitor analysis, benchmark analyses and assessing competitor products have been more important. About supplier innovations analysis enabler, analyzing 
innovations of complementary products manufacturers and establishing network connection with suppliers and manufacturers have been more important. In enterprise internal technological capabilities assessment enabler, preparing and analyzing the enterprise knowledge map and determining knowledge gap have had the greatest impact. And finally as regards applied sciences and technologies analysis enabler, technology trend analyses have played a greater role in measuring the related enabler. Also among the above mentioned enablers, the enterprise customers needs and wants assessment, assessment of new applied science and technology in power industry and analyzing innovations of suppliers and owners of complementary products have offered the greatest contributions.

Construct of innovation implementation: As regards new product design capability enabler, cross functional cooperation for designing and developing product, relationship with customers during product development process and simplicity considerations in design have had greater effects, though the difference between these indices and the rest ones in measuring the related enabler is not considerable.

Concerning new products manufacturing enabler, the index of applying advanced production techniques such as CNG, DNG and integrated information systems like MRP have played the greatest role. About technology transmission enabler, enterprises familiarity with technology transmission contracts and their legal rules and principles have been more important in comparing and assessing technical knowledge suppliers; albeit the rest indices have not had considerable difference with two first indices in measuring this enabler. In measuring innovative products commercialization enabler, the enterprise capability in undertaking such activities as publishing brochure, holding conference and workshop, etc., have had greater role.

Also among enablers, designing new products ability and innovative products commercialization capability have been the most important ones.

Construct of reconfiguration: In organization evolution enabler, decentralization of the enterprise decision-making trend and getting away from hierarchy structures in line with enterprise development have had the greatest role and then the index of enterprise governance proper system has been important. As regards intellectual property rights enabler, registering patent for the enterprise specific knowledge and design rights has had great importance. Also in measuring knowledge management and learning enabler, documentation of developed projects knowledge and designing processes for attaining, sharing and using the produced knowledge, have played the greatest roles.

It must be noted that among these enablers, organization evolution enabler and then intellectual property rights have had the greatest importance.

\section{CONCLUSION}

This study sought to design a model for dynamic capabilities evaluation in equipments manufacturing enterprises of Iran Power Industry. Considering four main elements of dynamic capabilities namely seizing opportunities, sensing opportunities, implementing innovation and reconfiguration, all related enablers and indices were identified with regard to dynamic capabilities and innovation management literature and Iran Power Industry properties. Also validity of all model constructs was approved via confirmatory factor analysis. By designing this model, one can assess accurately the level of attention that is paid to dynamic capabilities in the equipments manufacturing enterprises of Power Industry. On a large scale, enterprises survey in power industry and data collection and classification allow policy makers of this industry to establish research and development policies, innovation and technology management at power industry level through complete awareness of strengths and weaknesses of innovation development processes. Also enterprises managers may set the stage of these capabilities formation in their enterprises through using different tools including consulting firms' services in technology management or even hiring educated individuals in this field. It must be noted that, as referred in dynamic capabilities literature, these capabilities are based on learning and must be appeared in the enterprise in the form of model. Thus apparent attention without belief in the effect of these capabilities on all organizational processes will not have the required effectiveness. The proposed model that has been designed specifically for Iran Power Industry can be a basic model for all manufacturing enterprises of technological products particularly in developing countries; however, enablers and indices must be localized with regard to the properties of the related country and industry.

\section{REFERENCES}

Ambrosini, V. and C. Bowman, 2009. What are dynamic capabilities and are they a useful construct in strategic management? Int. J. Manag. Rev., 11(1): 29-49.

Bowman, C. and V. Ambrosini, 2003. How the resource-based and the dynamic capability views of the firm inform competitive and corporate level strategy. British J. Manage., 14: 289-303.

Cepeda, G., 2007. Dynamic capabilities and operational capabilities: A knowledge management perspective. J. Bus. Res., 60: 426-437.

Danneels, E., 2002. The dynamics of product innovation and firm competences. Strat. Manage. J., 23(12): 1095-1121. 
Di Stefano G., 2010. "Dynamic capabilities deconstructed $\%$ : a bibliographic investigation into the origins, development, and future directions of the research domain", Industrial and Corporate Change, 19(4):1187-1204.

Ellonen, H.K., 2009. Linking dynamic-capability portfolios and innovation outcomes. Technovation, 29: 753-762.

Helfat, C.E., 1997. Know-how and asset complementarity and dynamic capability accumulation: the case of R\&D. Strateg. Manage. J., 18(5): 339-360.

Human, H.A., 2008. Modeling structural equation by applying LISREL software, the organization of studying and editing human sciences books of universities (Samt). Human Sciences Research and Development Center.

Prieto, I.M., 2009. Building dynamic capabilities in product development: How do contextual antecedents matter? Scand. J. Manage., 25: 313-326.
Teece, D., G. Pisano and A. Shuen, 1997. Dynamic capabilities and strategic management. Strateg. Manage. J., 18(7): 509-533.

Teece, D., 2007. Explicating dynamic capabilities: the nature and micro foundations of (sustainable) enterprise performance. Strateg. Manage. J., 28: 1319-1350.

Teece, D., 2009. Dynamic Capabilities and Strategic Management. Oxford University Press, Oxford, pp: 65-136.

Verona, G. and D. Ravasi, 2003. Unbundling dynamic capabilities: an exploratory study of continuous product innovation. Ind. Corp. Change, 12(3): 577-606.

Zahra, S.A. and G. George, 2002. Absorptive capacity: A review, reconceptualization and extension. Acad. Manage. Rev., 27: 185-203. 